\title{
Degradation of key photosynthetic genes in the critically endangered semi-aquatic flowering plant Saniculiphyllum guangxiense (Saxifragaceae)
}

Ryan A. Folk ${ }^{1 *+} \mathbb{D}$, Neeka Sewnath ${ }^{2+}$, Chun-Lei Xiang ${ }^{3}$, Brandon T. Sinn ${ }^{4}$ and Robert P. Guralnick ${ }^{2}$

\begin{abstract}
Background: Plastid gene loss and pseudogenization has been widely documented in parasitic and mycoheterotrophic plants, which have relaxed selective constraints on photosynthetic function. More enigmatic are sporadic reports of pseudogenization and loss of important photosynthesis genes in lineages thought to be fully photosynthetic. Here we report the complete plastid genome of Saniculiphyllum guangxiense, a critically endangered and phylogenetically isolated plant lineage, along with genomic evidence of reduced chloroplast function. We also report 22 additional plastid genomes representing the diversity of its containing clade Saxifragales, characterizing gene content and placing variation in a broader phylogenetic context.

Results: We find that the plastid genome of Saniculiphyllum has experienced pseudogenization of five genes of the ndh complex ( $n d h A, n d h B, n d h D, n d h F$, and $n d h K)$, previously reported in flowering plants with an aquatic habit, as well as the surprising pseudogenization of two genes more central to photosynthesis (ccs $A$ and $\operatorname{cem} A$ ), contrasting with strong phylogenetic conservatism of plastid gene content in all other sampled Saxifragales. These genes participate in photooxidative protection, cytochrome synthesis, and carbon uptake. Nuclear paralogs exist for all seven plastid pseudogenes, yet these are also unlikely to be functional.

Conclusions: Saniculiphyllum appears to represent the greatest degree of plastid gene loss observed to date in any fully photosynthetic lineage, perhaps related to its extreme habitat specialization, yet plastid genome length, structure, and substitution rate are within the variation previously reported for photosynthetic plants. These results highlight the increasingly appreciated dynamism of plastid genomes, otherwise highly conserved across a billion years of green plant evolution, in plants with highly specialized life history traits.
\end{abstract}

Keywords: Plastid genome, Plastome, Pseudogene, Organelle, Saxifragaceae, Saniculiphyllum

\footnotetext{
* Correspondence: rfolk@biology.msstate.edu

${ }^{\dagger}$ Ryan A. Folk and Neeka Sewnath are co-first authors.

'Department of Biological Sciences, Mississippi State University, Mississippi, Mississippi State, USA

Full list of author information is available at the end of the article
}

(c) The Author(s). 2020 Open Access This article is licensed under a Creative Commons Attribution 4.0 International License, which permits use, sharing, adaptation, distribution and reproduction in any medium or format, as long as you give appropriate credit to the original author(s) and the source, provide a link to the Creative Commons licence, and indicate if changes were made. The images or other third party material in this article are included in the article's Creative Commons licence, unless indicated otherwise in a credit line to the material. If material is not included in the article's Creative Commons licence and your intended use is not permitted by statutory regulation or exceeds the permitted use, you will need to obtain permission directly from the copyright holder. To view a copy of this licence, visit http://creativecommons.org/licenses/by/4.0/ The Creative Commons Public Domain Dedication waiver (http://creativecommons.org/publicdomain/zero/1.0/) applies to the data made available in this article, unless otherwise stated in a credit line to the data. 


\section{Background}

Plastid genome structure and content is highly conserved among most of the $\sim 500,000$ species of land plants and their closest green algal relatives [1]. Widespread loss or pseudogenization of photosynthetic genes is a familiar feature of the plastids of diverse non-photosynthetic plant lineages, reflecting the reduced need for photosynthetic genes in lineages with heterotrophic strategies [2]. Accumulating evidence, however, has increasingly documented the pseudogenization and loss of "accessory" photosynthetic genes, only conditionally essential under stress, in fully photosynthetic plants. Although not universal, many of these pseudogenizations and losses are associated with highly specialized life history traits such as aquatic habit [3-5], carnivory [6, 7], and a mycoheterotrophic life-stage [1]; the functional significance of these losses remains enigmatic [8].

Plastid gene loss and pseudogenization is currently best studied in mycoheterotrophic, primarily nonphotosynthetic plants, which are under relatively relaxed selection on photosynthetic function. Remarkably, these plant lineages tend to follow a relatively predictable gene loss sequence, with early loss of photosynthetic accessory genes, primarily restricted to the $n d h$ complex [2], which is involved in photooxidative protection under stressful conditions $[8,9]$. This is eventually followed, in taxa with a longer evolutionary history of mycoheterotrophy, by loss of core photosynthetic genes. Housekeeping genes unrelated to photosynthesis, such as plastid ribosomal genes, are very resistant to loss [2]. Plastid gene content is less well-studied in fully photosynthetic life histories, but examples so far are consistent with this model. Gene loss to date has been restricted to portions of the $n d h$ complex $[3,8,10-12]$, which appears to be non-essential in model systems in the absence of abiotic stress $[9,13]$. Whether such losses of a functional copy from the plastid genome truly represent a loss of function remains uncertain, as there are many examples of gene loss or pseudogenization in organellar genomes accompanied by functional transfer to the nuclear genome $[14,15]$.

Saniculiphyllum guangxiense C.Y. Wu \& T.C. Ku is a semi-aquatic flowering plant now restricted to a miniscule area in Yunnan province, China. It grows partially submersed in the flow of small shaded waterfalls, and is critically endangered, with only four small extant populations in an area $\sim 10 \mathrm{~km}^{2}$ known to science, as well as several other populations known to have been extirpated within the last 30 years [16]. Consistent with the isolated morphological and ecological traits of this lineage within the family Saxifragaceae, its phylogenetic affinities remain uncertain. The most recent attempts to place this species [16-18] exhibit strong disagreement. Xiang et al. [16], using six loci generated by Sanger sequencing, could not confidently place this lineage beyond its membership in the
Heucheroid clade, while [17], using the same genetic loci, were able to place this lineage with $0.93-1.0$ posterior probability (depending on the analysis) as sister to the Boykinia group, a difference Deng et al. [17] attribute to alignment differences in a single rapidly evolving genetic locus (ITS). Relationships in these studies based on Sanger sequencing data differ substantially in several areas from those recovered on the basis of more than 300 nuclear genes [18], where Saniculiphyllum was placed with moderate bootstrap support (80\%) as sister to a clade containing the Astilbe and Boykinia groups.

In the course of organellar genome surveys across Saxifragales, we found anomalous photosynthetic gene sequences in Saniculiphyllum. Here, we report new plastid genome sequences of phylogenetically pivotal taxa, analyze plastid gene evolution across the Saxifragales, and place the Saniculiphyllum plastid genome in a phylogenetic context to assess evolutionary relationships and rates of plastid evolution. We seek to test whether Saniculiphyllum (1) has evidence for reduced photosynthetic function via pseudogenization of accessory photosynthetic genes, and (2) whether there is evidence for restored function of plastid pseudogenes via nuclear paralogs.

\section{Results}

\section{Assembly results}

For all samples, we successfully assembled a complete circular genome using NOVOPlasty. We individually confirmed all sequence features noted below by mapping the reads back to the assembly and found no evidence of misassembly.

\section{Basic genome features}

Saniculiphyllum has a chloroplast genome 151,704 bp long (Fig. 1). The large-scale structure of the genome is canonical for land plants, with an inverted repeat (26, $109 \mathrm{bp}$ ) separating the large-single-copy region (LSC; 84, $479 \mathrm{bp}$ ) and small-single-copy region (SSC, 15,007 bp). Excluding putative pseudogenes (below), gene content was as expected [20], comprising 73 distinct proteincoding genes, 30 tRNA genes, and 4 rRNA genes.

\section{Evidence for pseudogenization}

We used the presence of premature stop codons, frame shift mutations, missing canonical stop codons, and very large deletions as our criteria for pseudogenization (reviewed in [21]). We used gene models in the previously published $H$. parviflora var. saurensis genome [22] as well as comparisons across the newly annotated Saxifragales genomes presented here. We found genomic evidence for pseudogenization in 5 genes of the $n d h$ complex (ndhA, ndhB, ndhD, ndhF, and $n d h K$ ), and two other photosynthetic genes (cemA, ccsA), summarized in 


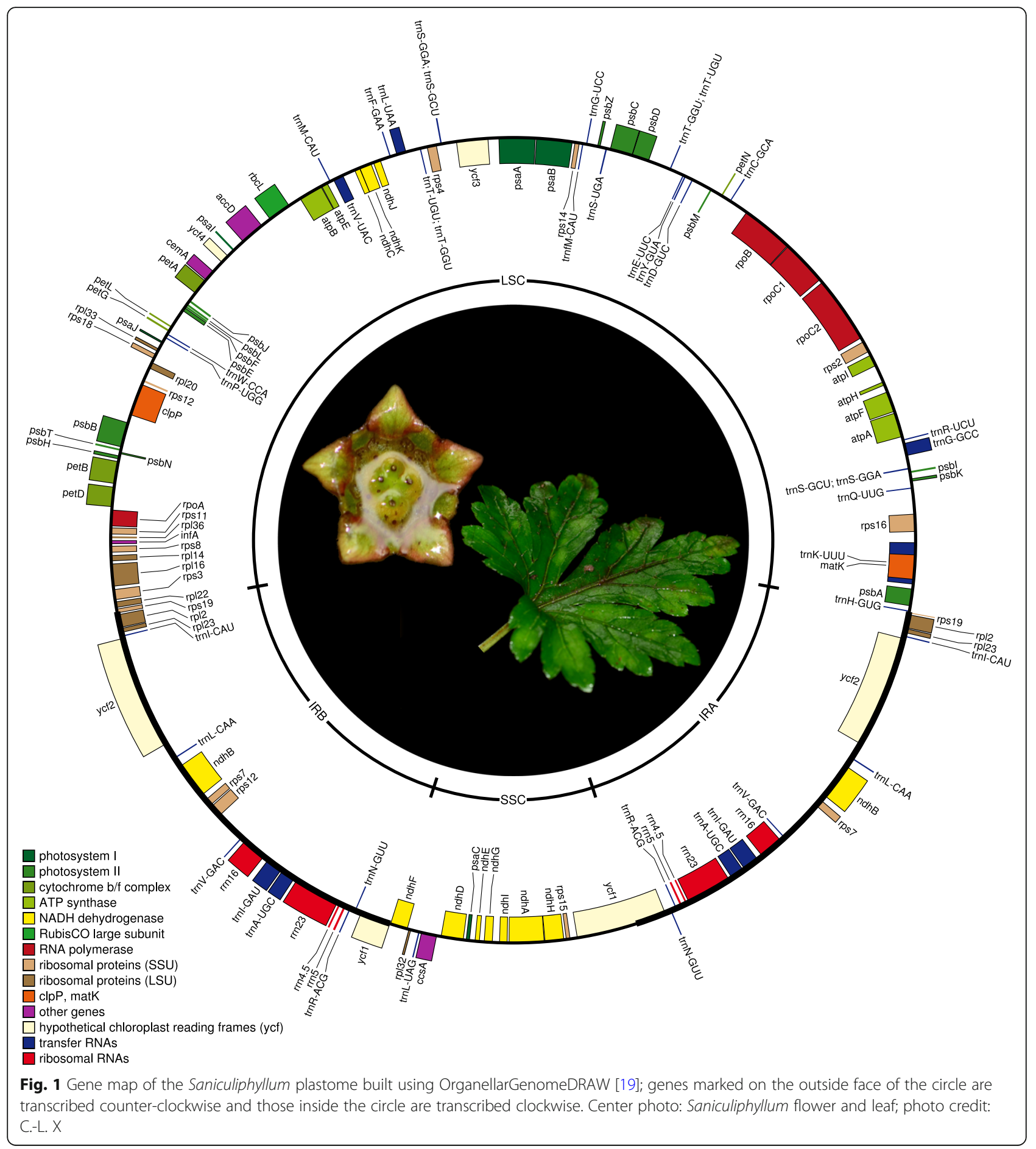

Table S2, Additional file 1). These were either driven by frame-shift mutations $(\operatorname{ccs} A, n d h A, n d h D$, and $n d h F)$ or by premature stop codons without a frameshift (due to a point mutation in $n d h B$ and a short inversion in $n d h K)$. Three genes (cemA, $n d h D$, and $n d h F)$ lack much of the conserved gene sequence due to large deletions $>100 \mathrm{bp}$. Among these, $\operatorname{cem} A$ has no premature stop codons, but it has an unconventional predicted protein size (5 extra amino acids) in a gene that otherwise shows no size variation in Saxifragales; while lacking $18 \%$ of the 3' end of this gene, the Saniculiphyllum copy has 137 additional bp before a novel stop codon, the sequence of which is homologous with adjacent intergenic spacers in its relatives, making it unlikely that this sequence is functional. Additionally, frameshift has resulted in the loss of the conserved stop codon site of $n d h A$. Predicted proteins of 
the three genes with large deletions (cemA, $n d h D$, and $n d h F$ ) have hydrophobicity outside the range of variation of other Saxifragales (cemA 50\% hydrophobic amino acids vs. the $95 \%$ confidence interval for other Saxifragales [50.4, 52.2\%]; $n d h D 47.8 \%$ vs. [62.2, 63.6\%]; $n d h F$ $54.9 \%$ vs. [55.6, 58.2\%]).

\section{Evidence for paralogs of pseudogenes}

For the three genes with large deletions (cemA, $n d h D$, and $n d h F$ ), we used the Leptarrhena sequence for the missing DNA to probe for potential nuclear or mitochondrial paralogs that could be functional; otherwise we used the entire CDS of this taxon. For all seven novel pseudogenes, we found evidence of paralogs outside of the assembled chloroplast genome, some of which are more conserved in sequence and lack the anomalous features of plastid pseudogenes (Supplementary Figs. S1-7). This includes copies of $\operatorname{cem} A, n d h D$, and $n d h F$ without the large deletions found in the plastid copy. However, with the exception of partial assembled sequences of $n d h F$, these paralogs all have either the same premature stop codons of the plastid copy or novel premature stop codons and are also unlikely to be functional. These paralogs likely originate in the nucleus on the basis of sequence coverage, which was orders of magnitude lower (SPAdes calculated $k$-mer coverage $1-5 \mathrm{X})$ than that expected for either the plastid or the mitochondrion ( $k$-mer coverage 100-2000X).

With the exception of $n d h K$, where we recovered 4 independent lineages of Saniculiphyllum paralogs, gene genealogies (Figs. S1-7, Additional file 1) were consistent with a recent origin of paralogs of the seven pseudogenes. In the $\operatorname{ccs} A$ gene genealogy, the Saxifraga stolonifera Curtis plastid ortholog was placed within a Saniculiphyllum clade without support, but otherwise $(\operatorname{cem} A, n d h A, n d h B, n d h D, n d h F)$ the Saniculiphyllum paralogs were recovered as monophyletic.

\section{Other anomalous features}

Several genes show slight variations in within-frame start and stop codon positions in Saxifragales, but Saniculiphyllum shows more variation than any other species we sampled, with four genes showing unique CDS terminations (atpB, cemA, rpl20, ycf2; Table S2, Additional file 1 ), of which none but rpl20 show any size variation in other Saxifragales species. While still within the typical length of photosynthetic plastid genomes, the Saniculiphyllum plastid genome as a whole was significantly smaller than the mean for Saxifragales species (onetailed t-test, $p=1.485 \mathrm{e}-10$ ).

We indirectly measured plastid genome copy number relative to background (mostly nuclear) DNA by calculating the percent of total genomic DNA mapping to the plastid genome. Lower values suggest lower copy number, either through fewer plastids or fewer genome copies per plastid. Interestingly, this was significantly smaller in Saniculiphyllum (3.4\%) compared to other Saxifragales (one-tailed t-test, $p=1.629 \mathrm{e}-07$ ); the mean of our Saxifragales species sampled here was $10.1 \%$, identical to a mean of $10.1 \%$ recovered with further Saxifragaceae species sampled in [22].

\section{Plastid genome diversity in Saxifragales}

The new plastid genomes sequenced in this study have no evidence of any structural rearrangements, underlining the strong conservatism of plastid genome structure in Saxifragales $[20,23]$ (the rare exception is Haloragaceae, distantly related to taxa discussed here; see [23, 24]). Other than Saniculiphyllum, we found no evidence at the DNA sequence level for pseudogenes beyond those previously documented for Saxifragales [20, 23] and many other angiosperms, namely $y c f 15$ and pseudogenes created by IR (inverted repeat) region boundaries within $y c f 1$ and $y c f 2$ (cf. Table S2, Additional file 1). The IR region, a major contributor to plastid genome size variation [25], shows similar trends (Table 1) to those documented previously in Saxifragales, where much like genome structure it is highly conserved [20]. However, the family Saxifragaceae shows a trend towards reduction, with some of the smallest IR regions in Saxifragales.

\section{Phylogenetic analysis}

The plastome alignment length was $172,773 \mathrm{bp}$, with $9.9 \%$ of the alignment comprising gap characters, and 38,332 parsimony-informative characters excluding the gap characters. Backbone relationships in the chloroplast genome phylogeny were congruent with recent phylogenomic work [18] (Fig. 2). Although receiving maximal bootstrap support, the placement of Saniculiphyllum we recovered is different from all previous efforts to place this taxon, none of which agree among themselves and none of which achieved greater than moderate support [16-18]. Our placement resembles previous work $[17,18]$ in placing Saniculiphyllum in a clade comprising the Astilbe Buch.Ham., Boykinia Raf., and Leptarrhena groups, but the novel placement reported here is sister to Leptarrhena.

\section{Substitution rate analysis}

Despite its divergent plastome features, genome-wide substitution rates did not appear elevated in Saniculiphyllum on the basis of phylogenetic branch length (Fig. 2), suggesting that at the nucleotide level negative selection is not substantially relaxed in this lineage. We further explored this hypothesis by explicitly testing for the presence of relaxed selection in the seven plastid gene copies with evidence of pseudogenization in Saniculiphyllum. We implemented this via $\omega(\mathrm{dN} / \mathrm{dS})$ ratios in PAML [27]. We used a model comparison approach on each gene tree to 
Table 1 Summary of new chloroplast genome sequences reported in this paper

\begin{tabular}{|c|c|c|c|c|c|c|c|c|}
\hline Species & $\begin{array}{l}\text { Field collecting } \\
\text { location }\end{array}$ & $\begin{array}{l}\text { Sequencing } \\
\text { technology }\end{array}$ & $\begin{array}{l}\text { Collection } \\
\text { data } \\
\text { (Herbarium) }\end{array}$ & $\begin{array}{l}\text { Genbank } \\
\text { accession }\end{array}$ & $\begin{array}{l}\text { Total sequencing } \\
\text { effort (millions of } \\
\text { reads) }\end{array}$ & $\begin{array}{l}\text { Plastid genome } \\
\text { mean coverage } \\
\text { (reduced data) }\end{array}$ & $\begin{array}{l}\text { Plastid } \\
\text { assembly } \\
\text { length }\end{array}$ & $\begin{array}{l}\text { Inverted } \\
\text { repeat } \\
\text { length }\end{array}$ \\
\hline $\begin{array}{l}\text { Boykinia } \\
\text { aconitifolia }\end{array}$ & $\begin{array}{l}\text { Alleghany } \\
\text { County, North } \\
\text { Carolina, U.S.A. }\end{array}$ & BGI-SEQ & $\begin{array}{l}\text { Folk } 249 \\
\text { (FLAS) }\end{array}$ & MN496058 & 734.3 & $374.8 \times$ & $\begin{array}{l}154,368 \\
\text { bp }\end{array}$ & $25,769 \mathrm{bp}$ \\
\hline $\begin{array}{l}\text { Cercidiphyllum } \\
\text { japonicum }\end{array}$ & Cultivation & BGI-SEQ & $\begin{array}{l}\text { Whitten } 5886 \\
\text { (FLAS) }\end{array}$ & MN496059 & 799.1 & $394.8 \times$ & $\begin{array}{l}159,897 \\
\text { bp }\end{array}$ & $26,434 \mathrm{bp}$ \\
\hline $\begin{array}{l}\text { Daphniphyllum } \\
\text { macropodum }\end{array}$ & Cultivation & BGI-SEQ & $\begin{array}{l}\text { Whitten } 5884 \\
\text { (FLAS) }\end{array}$ & MN496060 & 684.5 & $66.0 x$ & $\begin{array}{l}160,408 \\
\mathrm{bp}\end{array}$ & $26,605 \mathrm{bp}$ \\
\hline Fortunearia sinensis & Cultivation & BGI-SEQ & $\begin{array}{l}\text { Folk } 253 \\
\text { (FLAS) }\end{array}$ & MN496061 & 727.7 & $90.2 x$ & $\begin{array}{l}159,413 \\
\text { bp }\end{array}$ & $26,274 \mathrm{bp}$ \\
\hline Heuchera abramsii & $\begin{array}{l}\text { Los Angeles } \\
\text { County, California, } \\
\text { U.S.A. }\end{array}$ & $\begin{array}{l}\text { Illumina } \\
\text { HiSeq }\end{array}$ & Folk I-40 (OS) & MN496062 & 211.8 & $710.3 x$ & $\begin{array}{l}155,527 \\
\text { bp }\end{array}$ & $25,838 \mathrm{bp}$ \\
\hline Heuchera alba & $\begin{array}{l}\text { Pendleton } \\
\text { County, West } \\
\text { Virginia, U.S.A. }\end{array}$ & $\begin{array}{l}\text { Illumina } \\
\text { HiSeq }\end{array}$ & Folk 63 (OS) & MN496063 & 160.8 & $252.4 \times$ & $\begin{array}{l}155,360 \\
\text { bp }\end{array}$ & $25,632 \mathrm{bp}$ \\
\hline $\begin{array}{l}\text { Heuchera } \\
\text { caespitosa }\end{array}$ & $\begin{array}{l}\text { Ventura County, } \\
\text { California, U.S.A. }\end{array}$ & $\begin{array}{l}\text { Illumina } \\
\text { HiSeq }\end{array}$ & Folk 48 (OS) & MN496064 & 171.7 & $490.5 \times$ & $\begin{array}{l}155,520 \\
\mathrm{bp}\end{array}$ & $25,834 \mathrm{bp}$ \\
\hline $\begin{array}{l}\text { Heuchera } \\
\text { eastwoodiae }\end{array}$ & $\begin{array}{l}\text { Yavapai County, } \\
\text { Arizona, U.S.A. }\end{array}$ & $\begin{array}{l}\text { Illumina } \\
\text { HiSeq }\end{array}$ & Folk 35 (OS) & MN496065 & 82.3 & $336.0 \times$ & $\begin{array}{l}155,174 \\
\text { bp }\end{array}$ & $25,605 \mathrm{bp}$ \\
\hline $\begin{array}{l}\text { Heuchera } \\
\text { grossulariifolia var. } \\
\text { grossulariifolia }\end{array}$ & $\begin{array}{l}\text { Idaho County, } \\
\text { Idaho, U.S.A. }\end{array}$ & $\begin{array}{l}\text { Illumina } \\
\text { HiSeq }\end{array}$ & Folk 160 (OS) & MN496066 & 226.6 & $742.7 \times$ & $\begin{array}{l}155,493 \\
\text { bp }\end{array}$ & $25,645 \mathrm{bp}$ \\
\hline $\begin{array}{l}\text { Heuchera } \\
\text { longipetala var. } \\
\text { longipetala }\end{array}$ & Cultivation & $\begin{array}{l}\text { Illumina } \\
\text { HiSeq }\end{array}$ & Folk I-21 (OS) & MN496067 & 223.6 & $768.3 \times$ & $\begin{array}{l}155,418 \\
\text { bp }\end{array}$ & $25,638 \mathrm{bp}$ \\
\hline $\begin{array}{l}\text { Heuchera mexicana } \\
\text { var. mexicana }\end{array}$ & Cultivation & BGI-SEQ & Folk I-51 (OS) & MN496068 & 710.8 & $150.3 x$ & $\begin{array}{l}155,451 \\
\text { bp }\end{array}$ & $25,638 \mathrm{bp}$ \\
\hline $\begin{array}{l}\text { Heuchera parvifolia } \\
\text { var. utahensis }\end{array}$ & Cultivation & $\begin{array}{l}\text { Illumina } \\
\text { HiSeq }\end{array}$ & Folk I-56 (OS) & MN496069 & 273.3 & $738.5 \times$ & $\begin{array}{l}155,350 \\
\text { bp }\end{array}$ & $25,633 \mathrm{bp}$ \\
\hline $\begin{array}{l}\text { Leptarrhena } \\
\text { pyrolifolia }\end{array}$ & $\begin{array}{l}\text { Skagit County, } \\
\text { Washington, } \\
\text { U.S.A. }\end{array}$ & BGI-SEQ & $\begin{array}{l}\text { J.V. } \\
\text { Freudenstein } \\
3069 \text { (FLAS) }\end{array}$ & MN496070 & 752.2 & $253.8 \times$ & $\begin{array}{l}155,055 \\
\mathrm{bp}\end{array}$ & $25,781 \mathrm{bp}$ \\
\hline Mitella diphylla & $\begin{array}{l}\text { Monroe County, } \\
\text { Ohio, U.S.A. }\end{array}$ & $\begin{array}{l}\text { Illumina } \\
\text { HiSeq }\end{array}$ & Folk 88 (OS) & MN496071 & 230.8 & $357.0 x$ & $\begin{array}{l}155,646 \\
\text { bp }\end{array}$ & $25,753 \mathrm{bp}$ \\
\hline Mitella pentandra & $\begin{array}{l}\text { King County, } \\
\text { Washington, } \\
\text { U.S.A. }\end{array}$ & $\begin{array}{l}\text { Illumina } \\
\text { HiSeq }\end{array}$ & Folk 128 (OS) & MN496072 & 264.4 & $341.2 x$ & $\begin{array}{l}155,470 \\
\text { bp }\end{array}$ & $25,620 \mathrm{bp}$ \\
\hline Mukdenia rossii & Cultivation & BGI-SEQ & $\begin{array}{l}\text { Folk } 259 \\
\text { (FLAS) }\end{array}$ & MN496073 & 799.0 & $330.9 x$ & $\begin{array}{l}156,927 \\
\text { bp }\end{array}$ & $25,585 \mathrm{bp}$ \\
\hline $\begin{array}{l}\text { Oresitrophe } \\
\text { rupifraga }\end{array}$ & Cultivation & BGI-SEQ & $\begin{array}{l}\text { Folk } 257 \\
\text { (FLAS) }\end{array}$ & MN496074 & 678.1 & $261.3 x$ & $\begin{array}{l}156,787 \\
\text { bp }\end{array}$ & $25,586 \mathrm{bp}$ \\
\hline Ribes nevadense & $\begin{array}{l}\text { Shasta County, } \\
\text { California, U.S.A. }\end{array}$ & BGI-SEQ & $\begin{array}{l}\text { Nelson 2018- } \\
028 \text { (FLAS) }\end{array}$ & MN496075 & 782.7 & $234.3 x$ & $\begin{array}{l}157,715 \\
\text { bp }\end{array}$ & $25,887 \mathrm{bp}$ \\
\hline Ribes roezlii & $\begin{array}{l}\text { Shasta County, } \\
\text { California, U.S.A. }\end{array}$ & BGI-SEQ & $\begin{array}{l}\text { Nelson 2018- } \\
027 \text { (FLAS) }\end{array}$ & MN496076 & 723.6 & $262.7 x$ & $\begin{array}{l}157,781 \\
\text { bp }\end{array}$ & $25,967 \mathrm{bp}$ \\
\hline $\begin{array}{l}\text { Rodgersia } \\
\text { sambucifolia }\end{array}$ & Cultivation & BGI-SEQ & $\begin{array}{l}\text { R.A. Folk } 266 \\
\text { (FLAS) }\end{array}$ & MN496077 & 637.3 & $193.2 x$ & $\begin{array}{l}157,289 \\
\text { bp }\end{array}$ & $25,556 \mathrm{bp}$ \\
\hline $\begin{array}{l}\text { Saniculiphyllum } \\
\text { guangxiense }\end{array}$ & $\begin{array}{l}\text { Funing County, } \\
\text { Yunnan, China }\end{array}$ & $\begin{array}{l}\text { Illumina } \\
\text { HiSeq }\end{array}$ & $\begin{array}{l}\text { Xiang } 1271 \\
\text { (KUN) }\end{array}$ & MN496078 & 180.9 & $179.6 \times$ & $\begin{array}{l}151,704 \\
\text { bp }\end{array}$ & $26,109 \mathrm{bp}$ \\
\hline $\begin{array}{l}\text { Saxifraga } \\
\text { stolonifera }\end{array}$ & Cultivation & BGI-SEQ & $\begin{array}{l}\text { Folk } 258 \\
\text { (FLAS) }\end{array}$ & MN496079 & 623.5 & $238.2 x$ & $\begin{array}{l}151,060 \\
\text { bp }\end{array}$ & $25,412 b p$ \\
\hline Sycopsis sinensis & Cultivation & BGI-SEQ & $\begin{array}{l}\text { Folk } 256 \\
\text { (FLAS) }\end{array}$ & MN496080 & 746.2 & $117.7 \times$ & $\begin{array}{l}159,043 \\
b p\end{array}$ & $26,230 \mathrm{bp}$ \\
\hline
\end{tabular}




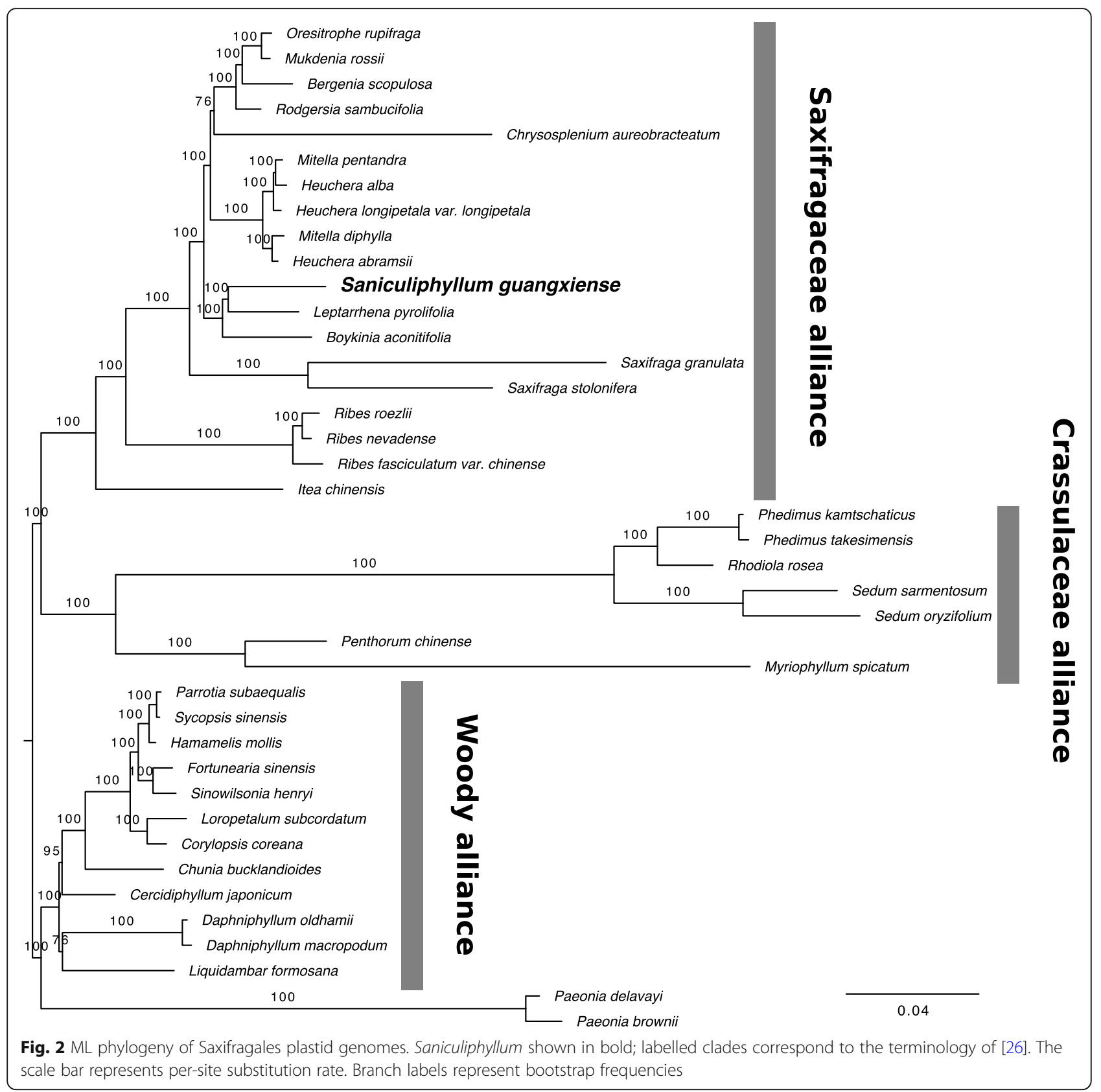

test whether the Saniculiphyllum branch experienced a shift in selection regime compared to its immediately ancestral branch. We did not find evidence of shifts in selection regimes (all $p>0.05$ ); likewise, we estimated $\mathrm{dN} /$ $\mathrm{dS}<1$ for the Saniculiphyllum branch across all seven pseudogenes (mean 0.0319), consistent with strong negative selection.

\section{Discussion}

\section{Pseudogenization}

In total, we found genomic evidence for seven putative pseudogenes in the Saniculiphyllum plastid genome.
Five of these ( $n d h A, n d h B, n d h D, n d h F$, and $n d h K)$, are genes of the $n d h$ complex. These genes are highly conserved across the land plants and related green algae [8]. Most losses of plastid gene function have been associated with parasitic and mycoheterotrophic plants, which presumably have few functional constraints on photosynthetic gene evolution. Pseudogenization or loss of genes in the $n d h$ complex has nevertheless been observed in several fully photosynthetic lineages with a variety of often highly specialized life history traits: woody perennials in Pinaceae and Gnetales (both gymnosperms), short-lived perennials in Geraniaceae (eudicots: 
rosids), alpine Circaeasteraceae (eudicots: Ranunculales), carnivorous and often aquatic plants of Lentibulariaceae (eudicots: asterids), various photosynthetic members of Orchidaceae (monocot), and aquatic members of Alismatales (monocot) and Podostemataceae (rosid [1, 3, 5, $8,10,13,28-30] ;)$. The primary function of the $n d h$ complex is thought to be reduction of photooxidative stress under fluctuating light conditions. While the $n d h$ complex appears dispensable under mild growth conditions [9], experimental evidence from knockouts of single $n d h$ genes shows that a complete and intact complex is essential for efficient photosynthesis and robust plant growth under stressful conditions [13].

More unusual than loss of $n d h$ function is the clear pseudogenization of two other photosynthesis-specific genes, for which we report the first absence in a fully photosynthetic plant. The gene $\operatorname{cem} A$ encodes a protein involved in carbon uptake; while not essential for photosynthesis, photosynthetic efficiency is reduced under high light environments in Chlamydomonas Ehrenb. mutants lacking this gene [31]. The gene $\operatorname{ccs} A$ encodes a protein involved in heme attachment to chloroplast cytochrome c [32]. ccsA, at least in Chlamydomonas, is essential for System II photosynthesis [32]. Both cemA and $\operatorname{css} A$ are conserved across primary photosynthetic eukaryotes and even cyanobacteria [31, 33].

\section{Evidence for paralogs in the nucleus}

We successfully found and assembled paralogs for all seven novel putative chloroplast pseudogenes in Saniculiphyllum. Many of these paralogs are of more conserved sequence than that of the assembled plastid genome; with the exception of $n d h K$ these appear to have originated primarily after the divergence of Saniculiphyllum from other Saxifragaceae lineages sampled here. On the basis of coverage, these are likely to represent NUPTs (nuclear sequences of plastid origin [34];). Our results are consistent with growing evidence of a slow transfer of organellar gene content into nuclear genomes [14, 34], a process associated with frequent non-homologous recombinational repair between these genomes [35]. While in some cases NUPTs are associated with restoration of function by coding for an imported functional photosynthetic protein [15], it is unlikely that Saniculiphyllum has any functional copies of these genes because almost all nuclear paralogs show signs of pseudogenization.

\section{Other genome anomalies}

We also observed unusual CDS terminations upstream or downstream of closely related Saxifragales plastid genomes in four genes (Table S2, Additional file 1); these do not result in frameshifts but expected protein products are of unexpected length. Although less dramatic than the pseudogenization patterns we observed, the lack of length conservation in Saniculiphyllum is markedly greater compared to close relatives. Likewise, while the Saniculiphyllum plastome is far longer than many non-photosynthetic plants (reviewed in [2]), it is among the shortest in Saxifragales due to large deletions in coding and non-coding regions throughout the plastome.

Despite having one of the most divergent plastid genomes in Saxifragales, there is no evidence for elevated substitution rates in Saniculiphyllum based on phylogenetic branch length estimated from the entire plastid genome (Fig. 2). Likewise, we implemented tests on $\mathrm{dN} / \mathrm{dS}$ ratios in the seven putative pseudogenes, demonstrating that Saniculiphyllum does not show significantly different selection regimes at the codon level compared to related lineages. These results suggest that Saniculiphyllum primarily differs in its plastid genome evolution via deletions and rare novel stop codons without any detectable global relaxation of purifying selection at the nucleotide level. Dosage of plastid DNA relative to the nucleus also appears to be low in Saniculiphyllum compared to relatives, likely representing either a reduction in plastids per cell or a reduction in genome copy number per plastid.

\section{Evolutionary relationships}

This work also represents the first robust phylogenomic placement of Saniculiphyllum, an important group for interpreting morphological evolution in Saxifragaceae [16]. We confirm a close relationship with the Boykinia and Leptarrhena groups, with which it shares axile placentation, determinate cymose inflorescences, and a strongly rhizomatous habit. However, representatives of the Astilbe group and several others have yet to be sampled; denser taxon sampling is needed to confirm the placement reported here.

\section{Conclusions}

Although chloroplast genome evolution in Saxifragales has been previously understood as very conservative [20], further sampling has revealed surprising plastid variation in one of its rarest and most unusual lineages. Similar but less extreme patterns of gene loss have been observed before in aquatic members of order Alismatales and Podostemaceae, and appear to represent multiple independent evolutionary events $[3,5]$, suggesting a possible relationship with life history. Like these lineages, Saniculiphyllum is highly specialized for partially submerged shaded waterfall environments, a stable habitat possibly conducive to relaxed selection on and loss of photosynthetic accessory genes. Nevertheless, this putative correlation is imperfect; while Alismatales contains some of the most thoroughly aquatic-adapted angiosperms, including the only examples of aquatic 
pollination [3], Myriophyllum, a completely aquatic Saxifragales lineage, shows conventional gene content [23], as do many other aquatic plastid genomes (e.g., Nelumbo Adans. [36], Nymphaea L. [37], Lemna L. [38]).

It is tempting to speculate on the relationship between loss of photosynthetic gene content and the imperiled conservation status of Saniculiphyllum since loss of abiotic stress-response genes would suggest a poor ability to respond to cope with environmental change. Unfortunately, we understand little of the functional significance of plastid gene content outside of model organisms. We highlight the need for characterization of plastid genome evolution, further examination its relationship to life history traits, and the continued promise of comparative phylogenomic approaches [39] for shedding light on this enigmatic pattern.

\section{Methods \\ Sampling}

We sequenced 23 plastomes in total to increase phylogenetic representation. Other than Saniculiphyllum, we sampled 16 further taxa of Saxifragaceae to cover most of the major recognized clades recognized in [17], and six further Saxifragales outgroups to increase representation in the woody alliance (cf. [26]). Most materials were obtained from horticultural sources; wild materials were collected with permission from the U.S. National Forest Service. Materials of Saniculiphyllum, which unfortunately does not currently have a legal conservation designation, were collected from an unprotected natural area. Sampling localities are given in Table 1. The species sampled in total, listed by major clade names, were: Darmera group: Mukdenia rossii, Oresitrophe rupifraga, Rodgersia sambucifolia; Boykinia group: Boykinia aconitifolia; Leptarrhena group: Leptarrhena pyrolifolia; Heuchera group: Heuchera abramsii, Heuchera alba, Heuchera caespitosa, Heuchera eastwoodiae, Heuchera grossulariifolia var. grossulariifolia, Heuchera longipetala var. longipetala, Heuchera mexicana var. mexicana, Heuchera parvifolia var. utahensis, Mitella diphylla, and Mitella pentandra; Saxifraga group: Saxifraga stolonifera; incertae sedis: Saniculiphyllum guangxiense. Outgroup taxa, listed by family, were: Cercidiphyllaceae: Cercidiphyllum japonicum. Daphniphyllaceae: Daphniphyllum macropodum; Grossulariaceae: Ribes nevadense and Ribes roezlii; Hamamelidaceae: Fortunearia sinensis and Sycopsis sinensis.

\section{DNA extraction and sequencing}

Whole genomic DNAs were isolated from silica-dried leaf material (Saniculiphyllum) or fresh material (all other taxa) using a modified CTAB extraction protocol [40]. Although our target was plastid DNA, we sequenced total DNA to enable paralog assembly (see below) and other future related work on mitochondrial and nuclear genomes. Taxa were chosen to represent lineages across Saxifragales. Sequencing was performed either at RAPiD Genomics (Gainesville, Florida, U.S.A.) with $150 \mathrm{bp}$ paired-end Illumina HiSeq sequencing or with $100 \mathrm{bp}$ paired-end BGISEQ-500 sequencing at BGI (Shenzhen, Guangdong, P.R. China), in both cases with an insert size of approximately $300 \mathrm{bp}$ (summarized in Table 1).

\section{Genome assembly}

We used NOVOPlasty v. 3.2 [41] to assemble chloroplast genomes for all sequenced taxa. For each sample, we ran two assemblies using $r b c L$ and matK seed reference genes from the plastid genome of Heuchera parviflora var. saurensis R.A. Folk [22]. Reads were not quality filtered following developer recommendations (see https://github.com/ndierckx/NOVOPlasty). We used the following parameters: $k$-mer $=39$, expected genome range 120,000-200,000 bp, insert size $300 \mathrm{bp}$, insert range $=1.8$, and insert range strict $=1.3$. We also used insert range fine-tuning to account for insert size variation between samples. When running NOVOPlasty on the entire dataset, we found it returned only partial plastid genome assemblies; datasets were normalized to 8 million raw reads per sample for HiSeq data and 4 million for BGI-SEQ samples ( 100-500X plastid coverage) using standard UNIX tools to achieve full-length assemblies of the plastid genome. Chloroplast genomes in most plants exist in both possible orientations of the small-single copy region relative to the rest of the genome [42], we manually standardized the orientation of the SSC region across samples prior to sequence alignment using Geneious R9.

Annotations were performed in Geneious R9 using the Heuchera parviflora reference plastid genome and a cutoff of $70 \%$ sequence identity, and draft annotated plastid genomes were aligned and manually examined for annotation accuracy. Additionally, all premature stop codons, inversions, frameshifting indels, and other unusual features were individually verified visually by mapping the original reads back to the assembled plastid genomes using the Geneious read mapping algorithm [43]. We also calculated the percent of chloroplast sequences in the total DNA from these mapped reads using SAMtools [44].

For the seven putative plastid pseudogenes, we searched for potential paralogs in the mitochondrial and nuclear genomes using aTRAM $2[45,46]$. aTRAM is a method for iterative, targeted assembly that implements commonly used de novo assembly modules on a reduced read set that has sequence homology with a seed sequence. Seed sequences were derived from the CDS sequence of the closest identified relative among our taxa, 
Leptarrhena pyrolifolia (D. Don) Ser. Ten iterations were used per assembly, and the assembler used was SPAdes v. 3.13.0 [47]; other options correspond to defaults. For these analyses, we extracted matching reads from the full Saniculiphyllum dataset ( 180,000,000 reads).

\section{Phylogenetics}

We conducted a maximum likelihood phylogenetic analysis both to reassess the relationships of Saniculiphyllum [16-18], and to assess rates of plastid substitution in a phylogenetic context. We analyzed the single-copy plastid sequence from each genome (i.e., with one copy of the inverted repeat), aligned them with MAFFT v. 7.388 [48], and ran phylogenetic analyses in RaxML v. 8.2.10 [49] under a GTR- $\Gamma$ model with 1000 bootstrap replicates (command "-f a"). Sites were partitioned as either coding (exonic proteincoding, rDNA, and tRNA) or non-coding. For this analysis, we sampled 22 further previously reported plastid genomes (Supplementary Table S1, Additional file 1), as well as generating a plastid genome assembly from previously reported short read data from Saxifraga granulata L. ([50]; SRA accession SRX665162), all chosen to represent phylogenetic diversity in Saxifragales, for a total of 40 taxa. We sampled 12 of 16 families, including complete representation of the Saxifragaceae alliance; the plastid of the parasitic family Cynomoriaceae has been sequenced, but this was deliberately excluded as it is on an extremely long branch [51]. Saxifragaceae sampling covers 8 of the 10 major clades recognized in [17]. Tree rooting follows [18].

For the paralog search in aTRAM, we placed recovered sequences in a phylogenetic context by extracting plastid sequences for each gene from the plastid genome alignment, trimming to the extent of chloroplast gene sequences and removing ambiguously aligned regions, and removing any sequences with fewer than $200 \mathrm{bp}$ remaining after these steps. We then built individual gene trees following the RAxML methods above.

\section{Tests for selection}

To test for relaxed selection in putative pseudogenes in Saniculiphyllum, we built two models for each of the seven gene trees: a full model allowing $\omega$ to vary across all branches, and a constrained model where Saniculiphyllum was constrained to have the same $\omega$ as the branch immediately ancestral to it. We used a likelihood ratio test to determine whether the constrained model could be rejected ( = a shift in selective regime along this phylogenetic branch). Since multiple tests were executed, multiple comparisons were corrected by the Hochberg method [52].

\section{Supplementary information}

Supplementary information accompanies this paper at https://doi.org/10. 1186/s12870-020-02533-x.

Additional file 1: Table S1. Summary of chloroplast genome sequences downloaded from GenBank for phylogenetic analyses. Table S2. Summary of premature stop codons, large/frame-shifting indels, and other anomalous genome features unique to Saniculiphyllum. Figure S1. $\mathrm{ML}$ gene phylogeny of $\operatorname{cs} A$, showing the phylogenetic placement of Saniculiphyllum paralogs (bold) among plastid orthologs. The Saniculiphyllum plastid copy is marked ***. Branch labels represent bootstrap frequencies; those below 50 are not plotted. Figure S2. ML gene phylogeny of cemA, showing the phylogenetic placement of Saniculiphyllum paralogs (bold) among plastid orthologs. The Saniculiphyllum plastid copy is marked ${ }^{* * *}$. Branch labels represent bootstrap frequencies; those below 50 are not plotted. Figure S3. ML gene phylogeny of $n d h A$, showing the phylogenetic placement of Saniculiphyllum paralogs (bold) among plastid orthologs. The Saniculiphyllum plastid copy is marked ***. Branch labels represent bootstrap frequencies; those below 50 are not plotted. Figure S4. ML gene phylogeny of $n d h B$, showing the phylogenetic placement of Saniculiphyllum paralogs (bold) among plastid orthologs. The

Saniculiphyllum plastid copy is marked ***. Branch labels represent bootstrap frequencies; those below 50 are not plotted. Figure S5. ML gene phylogeny of $n d h D$, showing the phylogenetic placement of Saniculiphyllum paralogs (bold) among plastid orthologs. The Saniculiphyllum plastid copy is marked ${ }^{* * *}$. Branch labels represent bootstrap frequencies; those below 50 are not plotted. Figure S6. ML gene phylogeny of $n d h F$, showing the phylogenetic placement of Saniculiphyllum paralogs (bold) among plastid orthologs. The Saniculiphyllum plastid copy is marked ${ }^{* *}$. Branch labels represent bootstrap frequencies; those below 50 are not plotted. Figure S7. ML gene phylogeny of $n d h K$, showing the phylogenetic placement of Saniculiphyllum paralogs (bold) among plastid orthologs. The Saniculiphyllum plastid copy is marked ***. Branch labels represent bootstrap frequencies; those below 50 are not plotted.

\section{Abbreviations}

CDS: Coding sequence; CTAB: Cetrimonium bromide; GTR-Г: General time reversible with gamma; ITS: Internal transcribed spacer; LSC: Long single copy [region]; NUPT: Nuclear plastid DNA; SSC: Small single copy [region]; SRA: Sequence Read Archive

\section{Acknowledgments}

D. Soltis and G. Wong are thanked for facilitating access to pilot short read data in connection with the 10KP project. J. Nelson, J. Xiang, and J.V.

Freudenstein are thanked for providing DNA materials; J. Ginori assisted with testing early assembly runs, and the late M. Whitten advised extensively on DNA extraction protocols.

\section{Authors' contributions}

R.A.F. conceived the study; R.A.F. and N.S. performed analyses; B.T.S., C.-L. X, and R.P.G consulted on analyses and interpretation; R.A.F. wrote the first manuscript draft; and all authors contributed to the final manuscript draft. All authors have read and approved the final version of this manuscript.

\section{Funding}

R.A.F. was supported by NSF DBI-1523667. There was no involvement of the funding providers in designing the study; collecting, analyzing or interpreting the data; or deciding to submit the paper for publication.

\section{Availability of data and materials}

The datasets supporting the conclusions of this article are available at Dryad (alignments, partition files, and tree topologies; https://doi.org/10.5061/dryad. mgqnk98vt), and at GenBank (accession numbers in Table S1; Additional file 1). Supplemental figures are available in Additional file 1.

\section{Ethics approval and consent to participate}

The authors have complied with all relevant institutional, national and international guidelines in collecting biological materials for this study. 
Collection permits for materials for sequencing were granted by the U.S. National Forest Service.

\section{Consent for publication}

Not applicable.

\section{Competing interests}

The authors declare that they have no competing interests.

\section{Author details}

'Department of Biological Sciences, Mississippi State University, Mississippi, Mississippi State, USA. ${ }^{2}$ Florida Museum of Natural History, University of Florida, Gainesville, Florida, USA. ${ }^{3}$ CAS Key Laboratory for Plant Diversity and Biogeography of East Asia, Kunming Institute of Botany, Chinese Academy of Sciences, Kunming, Yunnan, P. R. China. ${ }^{4}$ Department of Biology \& Earth Science, Otterbein University, Westerville, OH, USA.

\section{Received: 14 November 2019 Accepted: 28 June 2020} Published online: 08 July 2020

\section{References}

1. Wicke S, Schneeweiss GM, dePamphilis CW, Müller KF, Quandt D. The evolution of the plastid chromosome in land plants: gene content, gene order, gene function. Plant Mol Biol. 2011;76:273-97.

2. Barrett CF, Freudenstein JV, Li J, Mayfield-Jones DR, Perez L, Pires JC, et al. Investigating the path of plastid genome degradation in an earlytransitional clade of heterotrophic orchids, and implications for heterotrophic angiosperms. Mol Biol Evol. 2014;31:3095-112.

3. Peredo EL, King UM, Les DH. The plastid genome of Najas flexilis: adaptation to submersed environments is accompanied by the complete loss of the NDH complex in an aquatic angiosperm. PLoS One. 2013;8:e68591.

4. Ross TG, Barrett CF, Soto Gomez M, Lam VKY, Henriquez CL, Les DH, et al. Plastid phylogenomics and molecular evolution of Alismatales. Cladistics. 2016;32:160-78.

5. Bedoya AM, Ruhfel BR, Philbrick $C T$, Madriñán $S$, Bove $C P$, Mesterházy $A$, et al. Plastid genomes of five species of riverweeds (Podostemaceae): structural organization and comparative analysis in Malpighiales. Front Plant Sci. 2019:10:1035.

6. Wicke S, Schäferhoff B, dePamphilis CW, Müller KF. Disproportional plastome-wide increase of substitution rates and relaxed purifying selection in genes of carnivorous Lentibulariaceae. Mol Biol Evol. 2014;31:529-45.

7. Gruzdev EV, Kadnikov W, Beletsky AV, Kochieva EZ, Mardanov AV, Skryabin KG, et al. Plastid genomes of carnivorous plants Drosera rotundifolia and Nepenthes $\times$ ventrata reveal evolutionary patterns resembling those observed in parasitic plants. Int J Mol Sci. 2019;20. https://doi.org/10.3390/ ijms20174107

8. Martín M, Sabater B. Plastid ndh genes in plant evolution. Plant Physio Biochem. 2010;48:636-45.

9. Shikanai T, Endo T, Hashimoto T, Yamada Y, Asada K, Yokota A. Directed disruption of the tobacco $n d h B$ gene impairs cyclic electron flow around photosystem I. Proc Natl Acad Sci U S A. 1998:95:9705-9.

10. Lin C-S, Chen JJW, Chiu C-C, Hsiao HCW, Yang C-J, Jin X-H, et al. Concomitant loss of NDH complex-related genes within chloroplast and nuclear genomes in some orchids. Plant J. 2017;90:994-1006.

11. Chris Blazier J, Guisinger MM, Jansen RK. Recent loss of plastid-encoded ndh genes within Erodium (Geraniaceae). Plant Mol Biol. 2011;76:263-72.

12. Ranade SS, García-Gil MR, Rosselló JA. Non-functional plastid ndh gene fragments are present in the nuclear genome of Norway spruce (Picea abies L. Karsch): insights from in silico analysis of nuclear and organellar genomes. Mol Gen Genomics. 2016;291:935-41.

13. Ruhlman TA, Chang W-J, Chen JJW, Huang Y-T, Chan M-T, Zhang J, et al. $\mathrm{NDH}$ expression marks major transitions in plant evolution and reveals coordinate intracellular gene loss. BMC Plant Biol. 2015;15:100.

14. Richly E, Leister D. NUPTs in sequenced eukaryotes and their genomic organization in relation to NUMTs. Mol Biol Evol. 2004:21:1972-80.

15. Magee AM, Aspinall S, Rice DW, Cusack BP, Sémon M, Perry AS, et al. Localized hypermutation and associated gene losses in legume chloroplast genomes. Genome Res. 2010;20:1700-10.

16. Xiang C-L, Gitzendanner MA, Soltis DE, Peng H, Lei L-G. Phylogenetic placement of the enigmatic and critically endangered genus
Saniculiphyllum (Saxifragaceae) inferred from combined analysis of plastid and nuclear DNA sequences. Mol Phylogenet Evol. 2012;64:357-67.

17. Deng J-B, Drew BT, Mavrodiev EV, Gitzendanner MA, Soltis PS, Soltis DE. Phylogeny, divergence times, and historical biogeography of the angiosperm family Saxifragaceae. Mol Phylogenet Evol. 2015;83:86-98.

18. Folk RA, Stubbs RL, Mort ME, Cellinese N, Allen JM, Soltis PS, et al. Rates of niche and phenotype evolution lag behind diversification in a temperate radiation. Proc Natl Acad Sci U S A. 2019;116:10874-82.

19. Lohse M, Drechsel O, Kahlau S, Bock R. OrganellarGenomeDRAW--a suite of tools for generating physical maps of plastid and mitochondrial genomes and visualizing expression data sets. Nucleic Acids Res. 2013;41(Web Server issue):W575-81

20. Dong W, Xu C, Cheng T, Zhou S. Complete chloroplast genome of Sedum sarmentosum and chloroplast genome evolution in Saxifragales. PLoS One. 2013;8:e77965

21. Albalat R, Cañestro C. Evolution by gene loss. Nat Rev Genet. 2016;17: 379-91.

22. Folk RA, Mandel JR, Freudenstein JV. A protocol for targeted enrichment of intron-containing sequence markers for recent radiations: a phylogenomic example from Heuchera (Saxifragaceae). Appl Plant Sci. 2015;3:1500039.

23. Dong W, Xu C, Wu P, Cheng T, Yu J, Zhou S, et al. Resolving the systematic positions of enigmatic taxa: manipulating the chloroplast genome data of Saxifragales. Mol Phylogenet Evol. 2018;126:321-30.

24. Liao Y, Liu Y, Liu X, Lü T, Mbichi RW, Wan T, et al. The complete chloroplast genome of Myriophyllum spicatum reveals a 4-kb inversion and new insights regarding plastome evolution in Haloragaceae. Ecol Evol. 2020. https://doi. org/10.1002/ece3.6125.

25. Wang R-J, Cheng C-L, Chang C-C, Wu C-L, Su T-M, Chaw S-M. Dynamics and evolution of the inverted repeat-large single copy junctions in the chloroplast genomes of monocots. BMC Evol Biol. 2008:8:36.

26. Jian S, Soltis PS, Gitzendanner MA, Moore MJ, Li R, Hendry TA, et al. Resolving an ancient, rapid radiation in Saxifragales. Syst Biol. 2008;57:38-57.

27. Yang Z. PAML 4: phylogenetic analysis by maximum likelihood. Mol Biol Evol. 2007:24:1586-91.

28. Barrett CF, Sinn BT, Kennedy AH. Unprecedented parallel photosynthetic losses in a heterotrophic orchid genus. Mol Biol Evol. 2019. https://doi.org/ 10.1093/molbev/msz111

29. Weng $M-L$, Blazier JC, Govindu M, Jansen RK. Reconstruction of the ancestral plastid genome in Geraniaceae reveals a correlation between genome rearrangements, repeats, and nucleotide substitution rates. Mol Biol Evol. 2014;31:645-59.

30. Sun Y, Deng T, Zhang A, Moore MJ, Landis JB, Lin N, et al. The draft genome of the endangered, relictual plant Kingdonia uniflora (Circaeasteraceae, Ranunculales) reveals potential mechanisms and perils of evolutionary specialization. bioRxiv. 2020. https://doi.org/10.1101/2020.01.08. 898460

31. Rolland N, Dorne AJ, Amoroso G, Sültemeyer DF, Joyard J, Rochaix JD. Disruption of the plastid ycf10 open reading frame affects uptake of inorganic carbon in the chloroplast of Chlamydomonas. EMBO J. 1997;16: 6713-26.

32. Xie Z, Merchant S. The plastid-encoded $\operatorname{cs} A$ gene is required for heme attachment to chloroplast c-type cytochromes. J Biol Chem. 1996;271: 4632-9.

33. Hamel PP, Dreyfuss BW, Xie Z, Gabilly ST, Merchant S. Essential histidine and tryptophan residues in CCSA, a system II polytopic cytochrome c biogenesis protein. J Biol Chem. 2003;278:2593-603.

34. Timmis JN, Ayliffe MA, Huang CY, Martin W. Endosymbiotic gene transfer: organelle genomes forge eukaryotic chromosomes. Nat Rev Genet. 2004;5: 123-35.

35. Huang CY, Ayliffe MA, Timmis JN. Simple and complex nuclear loci created by newly transferred chloroplast DNA in tobacco. Proc Natl Acad Sci U S A. 2004;101:9710-5.

36. Wu Z, Gui S, Quan Z, Pan L, Wang S, Ke W, et al. A precise chloroplast genome of Nelumbo nucifera (Nelumbonaceae) evaluated with sanger, Illumina MiSeq, and PacBio RS II sequencing platforms: insight into the plastid evolution of basal eudicots. BMC Plant Biol. 2014;14:289.

37. Goremykin W, Hirsch-Ernst Kl, Wölfl S, Hellwig FH. The chloroplast genome of Nymphaea alba: whole-genome analyses and the problem of identifying the most basal angiosperm. Mol Biol Evol. 2004;21:1445-54.

38. Mardanov AV, Ravin NV, Kuznetsov BB, Samigullin TH, Antonov AS, Kolganova TV, et al. Complete sequence of the duckweed (Lemna minor) 
chloroplast genome: structural organization and phylogenetic relationships to other angiosperms. J Mol Evol. 2008;66:555-64.

39. Smith SD, Pennell MW, Dunn CW, Edwards SV. Phylogenetics is the new genetics (for most of biodiversity). Trends Ecol Evol. 2020;0. https://doi.org/ 10.1016/j.tree.2020.01.005.

40. Doyle JJ. A rapid DNA isolation procedure for small quantities of fresh leaf tissue. Phytochem Bull. 1987;19:11-5.

41. Dierckxsens N, Mardulyn P, Smits G. NOVOPlasty: de novo assembly of organelle genomes from whole genome data. Nucleic Acids Res. 2017;45:e18.

42. Wang W, Lanfear R. Long-reads reveal that the chloroplast genome exists in two distinct versions in most plants. Genome Biol Evol. 2019;11:3372-81.

43. Matthew Kearse, Shane Sturrock, and Peter Meintjes. The Geneious 6.0.3 Read Mapper. https://assets.geneious.com/documentation/geneious/ GeneiousReadMapper.pdf. Accessed 18 Sept 2019.

44. Li H, Handsaker B, Wysoker A, Fennell T, Ruan J, Homer N, et al. The sequence alignment/map format and SAMtools. Bioinformatics. 2009;25: 2078-9.

45. Allen JM, LaFrance R, Folk RA, Johnson KP, Guralnick RP. aTRAM 2.0: an improved, flexible locus assembler for NGS data. Evol Bioinformatics Online. 2018;14:1176934318774546

46. Allen JM, Huang DI, Cronk QC, Johnson KP. aTRAM - automated target restricted assembly method: a fast method for assembling loci across divergent taxa from next-generation sequencing data. BMC Bioinformatics. 2015;16:98.

47. Bankevich A, Nurk S, Antipov D, Gurevich AA, Dvorkin M, Kulikov AS, et al. SPAdes: a new genome assembly algorithm and its applications to singlecell sequencing. I Comput Biol. 2012;19:455-77.

48. Katoh $\mathrm{K}$, Asimenos $\mathrm{G}$, Toh H. Multiple alignment of DNA sequences with MAFFT. Methods Mol Biol. 2009;537:39-64.

49. Stamatakis A. RAxML-VI-HPC: maximum likelihood-based phylogenetic analyses with thousands of taxa and mixed models. Bioinformatics. 2006;22: 2688-90.

50. van der Meer S, Van Houdt JKJ, Maes GE, Hellemans B, Jacquemyn H. Microsatellite primers for the gynodioecious grassland perennial Saxifraga granulata (Saxifragaceae). Appl Plant Sci. 2014;2:1400040.

51. Bellot S, Cusimano N, Luo S, Sun G, Zarre S, Gröger A, et al. Assembled plastid and mitochondrial genomes, as well as nuclear genes, place the parasite family Cynomoriaceae in the Saxifragales. Genome Biol Evol. 2016;8: 2214-30.

52. Hochberg Y. A sharper Bonferroni procedure for multiple tests of significance. Biometrika. 1988;75:800-2.

\section{Publisher's Note}

Springer Nature remains neutral with regard to jurisdictional claims in published maps and institutional affiliations.

Ready to submit your research? Choose BMC and benefit from:

- fast, convenient online submission

- thorough peer review by experienced researchers in your field

- rapid publication on acceptance

- support for research data, including large and complex data types

- gold Open Access which fosters wider collaboration and increased citations

- maximum visibility for your research: over $100 \mathrm{M}$ website views per year

At BMC, research is always in progress.

Learn more biomedcentral.com/submissions 